\title{
A METHOD FOR THE QUANTITATIVE DETERMINATION OF THE CEPHALIN-CHOLESTEROL FLOCCULATION REACTION ${ }^{1}$
}

\author{
BY ABRAHAM SAIFER \\ (From the Veterans Administration Hospital, Manhattan Beach, Brooklyn, New York)
}

(Received for publication June 16, 1948)

The cephalin-cholesterol flocculation reaction of Hanger (1) has been found to be an extremely useful test in routine clinical work because of its simplicity and the very small number of false positive reactions in normal cases. Although positive reactions have been obtained in such diseases as malaria, pneumonia, septicemia, infectious mononucleosis, etc. (1-3), the test has found its widest application in the study of liver disease. A positive reaction in most cases indicates parenchymal cell injury and the test has been found most useful in the early diagnosis of liver disease $(4,5)$. Since the degree of flocculation of the cephalincholesterol emulsion by the patient's serum parallels the severity of the disease, serial determinations of this test have been found useful as an aid in the prognosis of various diseases $(1,4,6)$. At the present time, results are expressed in a qualitative manner, i.e., 0 to $4+$, and since negative values are often obtained before the jaundice has completely subsided, the test is of little diagnostic value late in the course of the disease (7).

Investigation of the flocculated material from positive cases has shown it to be a complex composed of a protein material, i.e., gamma globulin, attached to the cephalin-cholesterol emulsion (8). The probability of alpha and beta globulin from hepatitis sera also taking part in this reaction has recently been mentioned in the literature (9). The probable mechanism of the cephalin-cholesterol reaction including the inhibiting role of the albumin fraction has been described by Moore $e t$ al. (10) and is based on experimental studies made with electrophoretically separated fractions of normal and diseased human sera.

All the previous investigators have been concerned mainly with the nature of the protein part of the complex. The present investigation deals

\footnotetext{
1 Published with permission of the Chief Medical Director, Department of Medicine and Surgery, Veterans Administration, who assumes no responsibility for the opinions expressed or conclusions drawn by the author.
}

with the quantitative determination of the cholesterol content of the centrifuged material after the completion of the usual qualitative test.

\section{PROCEDURE}

The cephalin-cholesterol emulsion was prepared from the commercial product supplied by the Difco Laboratories, Inc., Detroit, Michigan, Lot No. 388716. The emulsion was prepared and the test run exactly as described by Hanger (1) except that the centrifuge tubes were kept in a dark closet as suggested by Neefe and Reinhold (11). Readings were made after 24 hours' standing and listed as $0, \pm,+,++,+++$, and ++++ , using Hanger's criteria of reading the results. No readings were made after 48 hours' standing as it was found that the sensitivity of the emulsion was such that about 10 per cent of the normal sera run gave + or ++ readings at that time (12). A saline blank, a known normal serum and a known ++++ serum were set up with each run.

After the completion of the qualitative test, the centrifuge tubes containing the samples were centrifuged at 3000 r.p.m. for exactly 15 minutes and the supernatant fluid was carefully poured off so as not to disturb the precipitate. The lips of the inverted tubes were allowed to drain on a piece of filter paper for a few seconds, the top inside surface of the tube wiped carefully with a clean piece of filter paper, and the tubes replaced upright in the rack. Approximately $0.1 \mathrm{ml}$. of distilled water was added to each centrifuge tube, followed by $4.5 \mathrm{ml}$. of acetic anhydride-dioxane mixture. The tubes were then placed in a boiling water bath and heated for 30 minutes or longer with occasional shaking. The tubes were then removed and cooled to room temperature and the contents transferred quantitatively to a colorimeter tube (or to a 5-ml. glass-stoppered graduated cylinder where individual cuvettes are used) graduated at $5.00 \mathrm{ml}$, with the aid of several small portions of the acetic anhydride-dioxane mixture and the contents diluted exactly to mark. The remainder of the procedure for the determination of the total cholesterol content of the precipitate is that described by Saifer and Kammerer (13). Small amounts of protein which may be washed into the colorimeter tube have a negligible effect on the accuracy of the method.

The results are expressed in cholesterol units (which are equivalent to the mg. per cent of total cholesterol for a $0.20-\mathrm{ml}$. serum sample) after subtraction of the saline blank value. 
TABLE I

Relationship of qualitative cephalin-cholesterol flocculation results to quantitative cholesterol unit values

\begin{tabular}{c|c|c|c}
\hline $\begin{array}{c}\text { Qualitative } \\
\text { values }\end{array}$ & $\begin{array}{c}\text { No. of } \\
\text { cases }\end{array}$ & $\begin{array}{c}\text { Range of } \\
\text { quantitative } \\
\text { cholesterol units }\end{array}$ & $\begin{array}{c}\text { Average } \\
\text { cholesterol } \\
\text { unit value }\end{array}$ \\
\hline $\begin{array}{c}\text { Negative } \\
\text { (All cases) }\end{array}$ & 48 & $0-204$ & 47 \\
\hline+ & 9 & $122-258$ & 188 \\
\hline++ & 12 & $129-332$ & 253 \\
\hline+++ & 13 & $243-473$ & 407 \\
\hline++++ & 13 & $410-633$ & 529 \\
\hline $\begin{array}{c}\text { Negative } \\
\text { (Normals } \\
\text { only) }\end{array}$ & 20 & $0-103$ & 43 \\
\hline
\end{tabular}

RESULTS

Some 20 normal sera and 80 sera from hospital patients, including a large group of cases with liver disease, were run by the procedure described above. The qualitative results obtained by the Hanger method, the number of cases in each group, the range of quantitative cholesterol units for each group and the average quantitative cholesterol value for each qualitative group are given in Table I. The results obtained indicate that there is a direct quantitative relationship between the quali-

TABLE II

Reproducibility of quantitative cholesterol unit values obtained for normal and pathological sera

\begin{tabular}{|c|c|c|c|c|}
\hline $\begin{array}{c}\text { Patient and } \\
\text { diagnosis }\end{array}$ & $\begin{array}{c}\text { Qualitative } \\
\text { values }\end{array}$ & $\begin{array}{c}\text { Quanti- } \\
\text { tative } \\
\text { cholesterol } \\
\text { units }\end{array}$ & $\begin{array}{c}\text { Quantitative } \\
\text { cholesterol } \\
\text { units } \\
\text { (average) }\end{array}$ & $\begin{array}{c}\text { Probable } \\
\text { erroor of a } \\
\text { single } \\
\text { determin. } \\
\text { cholest. } \\
\text { units }\end{array}$ \\
\hline $\begin{array}{c}\text { No. } 1 \\
\text { (Normal) }\end{array}$ & $\begin{array}{l}\mathbf{0} \\
\mathbf{0} \\
\mathbf{0}\end{array}$ & $\begin{array}{l}17 \\
30 \\
23\end{array}$ & 23 & 4.4 \\
\hline $\begin{array}{c}\text { No. } 2 \\
\text { (Normal) }\end{array}$ & $\begin{array}{l}0 \\
0 \\
0\end{array}$ & $\begin{array}{r}11 \\
6 \\
8\end{array}$ & 8 & 4.2 \\
\hline $\begin{array}{c}\text { No. } 3 \\
\text { (Unknown) }\end{array}$ & $\begin{array}{l}+ \\
+\end{array}$ & $\begin{array}{l}205 \\
210 \\
202\end{array}$ & 206 & 3.0 \\
\hline $\begin{array}{c}\text { No. } 4 \\
\text { (Infectious } \\
\text { hepatitis) }\end{array}$ & $\begin{array}{l}3+ \\
3+ \\
3+\end{array}$ & $\begin{array}{l}485 \\
476 \\
478\end{array}$ & 480 & 3.7 \\
\hline $\begin{array}{l}\text { No. } 5 \\
\text { Cirrhosis }\end{array}$ & $\begin{array}{l}4+ \\
4+ \\
4+\end{array}$ & $\begin{array}{l}642 \\
648 \\
636\end{array}$ & 642 & 4.1 \\
\hline
\end{tabular}

tative results by the Hanger method and the quantitative cholesterol unit values of the centrifuged complex.

To check the reproducibility of the method, a number of normal and pathological sera were run in triplicate by the above method. The quantitative cholesterol units obtained together with the errors involved in the procedure are given in Table II. In Table IV, the reproducibility of the method is again shown by the relatively constant cholesterol unit values obtained on repeated analysis, at intervals, of the author's own serum. The data in Table III are presented to show the effect

TABLE III

Effect of using different cephalin-cholesterol emulsions on the quantitative cholesterol unil values obtained with the same sera.

\begin{tabular}{|c|c|c|c|c|c|}
\hline $\begin{array}{l}\text { Patient } \\
\text { and } \\
\text { diagnosis }\end{array}$ & Emulsion & $\begin{array}{l}\text { Quali- } \\
\text { tative } \\
\text { values }\end{array}$ & $\begin{array}{c}\text { Quanti- } \\
\text { tative } \\
\text { cholesterol } \\
\text { units }\end{array}$ & $\begin{array}{l}\text { Cholesterol } \\
\text { unit value } \\
\text { (Average) }\end{array}$ & $\begin{array}{c}\text { Probable } \\
\text { error of a } \\
\text { single } \\
\text { determin. } \\
\text { cholest. } \\
\text { units }\end{array}$ \\
\hline $\begin{array}{c}\text { No. } 8 \\
\text { Normal }\end{array}$ & $\begin{array}{l}\text { I } \\
\text { II } \\
\text { III }\end{array}$ & $\begin{array}{l}0 \\
0 \\
0\end{array}$ & $\begin{array}{l}0 \\
7 \\
5\end{array}$ & 4 & 2.8 \\
\hline $\begin{array}{l}\text { No. } 11 \\
\text { Normal }\end{array}$ & $\begin{array}{l}\text { I } \\
\text { II } \\
\text { III }\end{array}$ & $\begin{array}{l}0 \\
0 \\
0\end{array}$ & $\begin{array}{l}0 \\
4 \\
2\end{array}$ & 2 & 1.4 \\
\hline $\begin{array}{c}\text { No. } 12 \\
\text { Unknown }\end{array}$ & $\begin{array}{l}\text { I } \\
\text { II } \\
\text { III }\end{array}$ & $\begin{array}{l}2+ \\
2+ \\
2+\end{array}$ & $\begin{array}{l}302 \\
318 \\
294\end{array}$ & 305 & 9.3 \\
\hline $\begin{array}{l}\text { No. } 5 \\
\text { Cirrhosis }\end{array}$ & $\begin{array}{l}\text { I } \\
\text { II } \\
\text { III }\end{array}$ & $\begin{array}{l}4+ \\
4+ \\
4+\end{array}$ & $\begin{array}{l}531 \\
558 \\
502\end{array}$ & 530 & 19.6 \\
\hline
\end{tabular}

on the same sera, normal or pathological, of different cephalin-cholesterol emulsions. Two of these emulsions, I and II, were prepared from the same lot of Difco antigen while emulsion III was prepared from another lot from the same company. The results of these experiments together with the errors involved in using the different emulsions are given in Table III.

To determine whether this procedure could be used in the prognosis of liver disease, a number of typical cases were followed by means of serial quantitative determinations at frequent intervals. The data obtained in these runs are presented in Table IV, together with other pertinent data, e.g., thymol turbidity, bromsulfalein, icteric index, etc., relating to the clinical condition of the patient. 
TABLE IV

A comparison of serial qualitative and quantitative cephalin-cholesterol flocculation lests as an aid in the prognosis of liver disease

\begin{tabular}{|c|c|c|c|c|c|c|c|c|c|c|c|}
\hline $\begin{array}{c}\text { Patient and } \\
\text { diagnosis }\end{array}$ & $\begin{array}{c}\text { Date of test: } \\
1 / 8\end{array}$ & $1 / 13$ & $1 / 16$ & $1 / 18$ & $1 / 22$ & $1 / 27$ & $1 / 29$ & $2 / 3$ & $2 / 10$ & $2 / 17$ & $2 / 25$ \\
\hline $\begin{array}{l}\text { No. } 4 \\
\text { Infectious } \\
\text { hepa titis }\end{array}$ & $\begin{array}{c}4+ \\
516 \\
I I=16\end{array}$ & $\begin{array}{l}4+ \\
493\end{array}$ & $\begin{array}{l}4+ \\
443\end{array}$ & $\begin{array}{l}3+ \\
430\end{array}$ & $\begin{array}{l}3+ \\
371\end{array}$ & $\begin{array}{c}3+ \\
367 \\
\mathrm{TT}=11\end{array}$ & - & - & $\begin{array}{c}3+ \\
377 \\
T T=9\end{array}$ & $\begin{array}{c}2+ \\
359 \\
T T=9\end{array}$ & $\begin{array}{c}1+ \\
149 \\
\mathrm{TT}=6\end{array}$ \\
\hline $\begin{array}{r}\text { No. } 5 \\
\text { Cirrhosis }\end{array}$ & $\begin{array}{c}4+ \\
483 \\
\text { Brom }=32\end{array}$ & $\begin{array}{l}4+ \\
540\end{array}$ & $\begin{array}{l}4+ \\
510\end{array}$ & $\begin{array}{l}4+ \\
484\end{array}$ & & & & & $\begin{array}{c}4+ \\
642 \\
T T=6\end{array}$ & & ' \\
\hline $\begin{array}{l}\text { No. } 6 \\
\text { Infectious } \\
\text { hepatitis }\end{array}$ & - & $\begin{array}{l}3+ \\
399\end{array}$ & $\begin{array}{c}3+ \\
415 \\
\text { Brom }=4.5 \\
I I=8.6\end{array}$ & - & $\begin{array}{c}3+^{*} \\
461 \\
\text { Brom }=0.5 \\
I I=6.3\end{array}$ & - & $\begin{array}{c}3+ \\
523 \\
\mathrm{TT}=3\end{array}$ & $\begin{array}{c}3+ \\
538 \\
T T=3\end{array}$ & $\begin{array}{c}3+ \\
492 \\
\mathrm{TT}=3\end{array}$ & $\begin{array}{l}3+ \\
482\end{array}$ & $\begin{array}{l}2+ \\
342\end{array}$ \\
\hline $\begin{array}{l}\text { No. } 7 \\
\text { Infectious } \\
\text { hepatitis }\end{array}$ & $\begin{array}{l}3+ \\
355\end{array}$ & - & - & $\begin{array}{c}0 \\
118 \\
T T=9\end{array}$ & - & - & - & $\begin{array}{c}1+ \\
155 \\
\mathrm{Bil}=3.0\end{array}$ & $\begin{array}{c}2+ \\
273 \\
\mathrm{TT}=7\end{array}$ & & \\
\hline $\begin{array}{l}\text { No. } 8 \\
\text { Normal }\end{array}$ & - & - & $\begin{array}{l}0 \\
4\end{array}$ & $\begin{array}{l}0 \\
2\end{array}$ & - & $\begin{array}{l}0 \\
4\end{array}$ & - & - & - & $\begin{array}{l}0 \\
6\end{array}$ & - \\
\hline
\end{tabular}

$0 \quad$ = negative cephalin-cholesterol readings.

TT $=$ Thymol Turbidity units.

II = Icteric Index.

To determine whether cholesterol played a similar role in the thymol flocculation test of Neefe (14), a number of normal and abnormal sera were treated with the thymol reagent of Maclagan (15) and after measurement of the thymol turbidity, the contents were transferred to centrifuge tubes and allowed to stand for 24 hours in a dark closet. The thymol flocculation readings were then made and the contents centrifuged at 3000 r.p.m. for 15 minutes. The remainder of the procedure was performed exactly as described above for the cephalin-cholesterol flocculation reaction. The re-

TABLE V

Relationship of thymol flocculation and cephalin-cholesterol flocculation readings to quantitative cholesterol units of centrifuged complex

\begin{tabular}{c|c|c|c|c}
\hline \hline $\begin{array}{c}\text { Patient } \\
\text { and } \\
\text { diagnosis }\end{array}$ & $\begin{array}{c}\text { Cephalin- } \\
\text { cholesterol } \\
\text { values } \\
\text { qualitative }\end{array}$ & $\begin{array}{c}\text { Cephalin- } \\
\text { cholesterol } \\
\text { values } \\
\text { quantitative }\end{array}$ & $\begin{array}{c}\text { Thymol } \\
\text { flocculation } \\
\text { values } \\
\text { qualitative }\end{array}$ & $\begin{array}{c}\text { Thymol } \\
\text { focculation } \\
\text { values- } \\
\text { quantitative }\end{array}$ \\
\hline $\begin{array}{c}\text { No. 5 } \\
\text { Cirrhosis }\end{array}$ & $4+$ & 483 & $3+$ & 32 \\
\hline $\begin{array}{c}\text { No. 9 } \\
\text { Acute } \\
\text { hepatitis }\end{array}$ & $4+$ & 410 & 0 & 2 \\
\hline $\begin{array}{c}\text { No. 10 } \\
\text { Ulcerative } \\
\text { colitis }\end{array}$ & $3+$ & 329 & 0 & 16 \\
\hline $\begin{array}{c}\text { No. 8 } \\
\text { Normal }\end{array}$ & 0 & 7 & 0 & 0 \\
\hline
\end{tabular}

$\mathrm{Bil}=$ total Bilirubin (mg. per cent).

Brom = Bromsulfalein (per cent retained).

* Patient hospitalized.

sults obtained in this run are given in Table V. Only slight differences between the cholesterol content of negative and strongly positive thymol flocculation reactions are obtained upon analysis of the centrifuged material, as compared to the very large differences obtained for the cephalin-cholesterol precipitates of the same sera.

TABLE VI

Effect of dilution with physiological saline of normal and pathological sera on the cephalin-cholesterol flocculation test as determined by the qualitative and quantitative procedures*

\begin{tabular}{|c|c|c|c|c|c|c|}
\hline \multirow{3}{*}{$\begin{array}{l}\text { Quan- } \\
\text { tity } \\
\text { of } \\
\text { serum } \\
\text { ml. }\end{array}$} & \multicolumn{6}{|c|}{ Patient and diagnosis } \\
\hline & No. 8 & No. 13 & No. 5 & No. 4 & No. 12 & No. 7 \\
\hline & Normal & Normal & $\begin{array}{c}\text { Cirrhosis } \\
\text { of liver }\end{array}$ & Hepatitis & Unknown & Hepatitis \\
\hline 0.20 & $2(0)$ & $96(0)$ & $606(4+)$ & $430(3+)$ & $289(2+)$ & $258(1+)$ \\
\hline 0.10 & $183(1+)$ & $415(3+)$ & $657(4+)$ & $609(4+)$ & $418(3+)$ & $335(3+)$ \\
\hline 0.05 & $604(4+)$ & $658(4+)$ & $695(4+)$ & $734(4+)$ & $684(4+)$ & $731(4+)$ \\
\hline 0.02 & $701(4+)$ & $653(4+)$ & $473(4+)$ & $733(4+)$ & $695(4+)$ & $738(4+)$ \\
\hline 0.01 & $707(4+)$ & $301(4+)$ & $325(4+)$ & $725(4+)$ & $616(4+)$ & $757(4+)$ \\
\hline 0.005 & $430(4+)$ & $61(4+)$ & $212(4+)$ & $450(4+)$ & $279(4+)$ & $165(4+)$ \\
\hline
\end{tabular}

* Note: Figures in parentheses give the qualitative cephalin-cholesterol flocculation readings.

All cholesterol unit values were calculated as if each tube contained $0.20 \mathrm{ml}$. of serum. The true cholesterol unit values can be obtained by multiplying the values in the table by the factor ( $\left.\frac{0.20}{\text { Quantity of serum used }}\right)$. 
Bruger (16) and Mirsky and von Brecht (17) have shown that the dilution of both normal and pathological sera lead to an increase in the degree of flocculation by the Hanger method. It was decided to reinvestigate the dilution phenomena by the quantitative procedure so as to determine whether the proportion of serum to emulsion presently used in the qualitative method is the most suitable one for the purpose of distinguishing normal from abnormal sera. The results obtained in this run are given in Table VI.

\section{ANALYSIS OF RESULTS}

The 95 cases given in Table I furnish ample evidence in support of the fundamental observation of this paper, that there is a quantitative relationship between the degree of flocculation and the cholesterol content of the centrifuged complex. All normal individuals, who gave negative qualitative results, gave quantitative cholesterol unit values of 103 or less with an average value of 43 cholesterol units. Negative qualitative values which gave more than 100 cholesterol units were usually known liver disease cases in the convalescent stage of the disease when the Hanger test is known to become negative while the thymol turbidity values still remain elevated (18).

Between the various qualitative groupings, i.e., 0 to $4+$, there is a spread of between 65 to 154 cholesterol units between each group. The overlapping values for each of the various groupings given under "range of cholesterol units" is to be expected because of the personal error involved in deciding the exact qualitative reading of any given determination. The average cholesterol value for each group therefore furnishes a better index for the experimental fact that the quantitative cholesterol unit value increases with the degree of flocculation.

The data given in Table II illustrate the reproducibility of the quantitative method for the same normal or pathological sera when determined with the same cephalin-cholesterol emulsion. While the percentage error is greatest for the negative qualitative values and is least for the higher qualitative values, the probable error of any single determination remains remarkably constant over the entire range at about \pm 4 cholesterol units.

The effect of using different cephalin-cholesterol emulsions on the quantitative cholesterol unit values obtained with the same sera is shown by the data which are given in Table III. Emulsion II seems to give consistently the highest values for each of the sera while Emulsion III gives the lowest values. Unlike the results obtained in Table II, the probable error of a single determination appears to increase markedly with the qualitative reading and for a $4+$ qualitative result, the error is approximately \pm 20 cholesterol units although it is only about \pm 4 units for a negative qualitative test.

That reproducible results can be obtained with the same sera when different emulsions are used are shown by the data on the author's own serum (No. 8.) in Table IV. The cephalin-cholesterol emulsions were freshly prepared on the date given together with several saline blanks. The quantitative cholesterol values were obtained after subtraction of the lowest saline blank. The values obtained for the same individual are remarkably consistent, giving an average cholesterol value of 4 units, and are all well within the expected error of \pm 4 cholesterol units.

In Table IV, data are presented to illustrate the use of the method to follow the clinical course of a number of selected cases by means of serial determinations by the quantitative procedure. The same lot of Difco cephalin-cholesterol antigen was used for all of these studies although a fresh emulsion was prepared for each day's run.

Patient No. 4 represents a typical case of infectious hepatitis with an uneventful recovery on prolonged bed-rest with a high-protein, high-carbohydrate diet. The quantitative cholesterol values show a continuous decrease, except in one instance, and parallel quite closely the decrease in thymol turbidity values. It should be noted that the decrease in the cholesterol unit value anticipates in each instance the decrease in the qualitative value. In the one instance where there is a slight rise, i.e., from 367 to 377 , instead of a fall in the quantitative value, the change is 10 units whereas it has been previously mentioned that changes of less than 20 units were not to be considered as significant because of the difficulty in obtaining a reproducible emulsion.

Patient No. 5 represents a typical case of cirrhosis of long duration and has consistently shown a bromsulfalein retention value of about 30 per 
cent. This patient has repeatedly given $4+$ qualitative cephalin-cholesterol flocculation values with occasional 3 + values and relatively normal thymol turbidity values over a period of about a year. The quantitative cholesterol unit values obtained indicate the possibility of a rhythmic pattern for this disease which may parallel periods of increasing or decreasing parenchymal cell injury.

Patient No. 6 represents a recurrent case of infectious hepatitis which was found upon routine testing previous to hospitalization. Although the qualitative readings remained almost constantly at $3+$ for the entire period of observation, the quantitative readings show a progressive rise followed by a decline after a period of hospitalization and treatment. In this case all other liver function tests were found to be normal.

Patient No. 7 illustrates a case of infectious hepatitis which went from a $3+$ to a negative cephalincholesterol qualitative value in a relatively short space of time. It should be noted that the quantitative cholesterol value remained above 100 units and the thymol turbidity value was still considerably elevated, indicating that the disease was active. The patient was permitted to resume activity and suffered a relapse as indicated by the increasing qualitative and quantitative cephalin-cholesterol flocculation values.

The data shown in Table $\mathrm{V}$ indicate that the thymol flocculation test does not lend itself to the same quantitative differentiation by means of cholesterol determinations as does the cephalincholesterol flocculation test. The differences between a 3 + flocculation and a negative serum, as measured in cholesterol units, were so slight as to be within the experimental error of the method. This furnishes additional experimental evidence of the differences between the two tests in addition to that given by Recant et al. (19).

The data shown in Table VI on the effect of dilution with physiological saline of normal and abnormal sera on the cephalin-cholesterol flocculation test are a good example of the use of the quantitative method as a means of studying the various factors which influence the Hanger reaction. All the sera tested, both normal and pathological, exhibit an increase in the degree of flocculation with increasing dilution of the sera until a maximum value is reached, after which continued dilution causes a rapid decline in the amount of the flocculated material as measured in quantitative cholesterol units. It should be noted that it would be difficult, if not impossible, to draw similar conclusions from the qualitative data as given in Table VI, as in each instance when the quantity of sera used is less than $0.05 \mathrm{ml}$., the supernatant fluid is water clear and would be read a $4+$ by the Hanger method although the actual amount of precipitate may vary markedly. No evidence could be found in the literature to justify the proportions of serum, saline and emulsion presently used in the Hanger test. The data in Table VI show that the greatest differences between normal and pathological cases are obtained for $0.20 \mathrm{ml}$. of serum and that the proportions of serum, saline and emulsion chosen by Hanger are the best ones for the purpose.

The data in Table VI also appear to confirm the views of Moore, Pierson, Hanger and Moore (10) of the presence of a reactive gamma globulin and an inhibitory substance in the albumin fraction in all sera whether normal or abnormal. Dilution at first appears to dilute the inhibitory substance to a greater extent than the gamma globulin so that there is at first an increase in the amount of flocculated material until a point is reached where further dilution causes a decrease in the amount of the flocculated material. It should be noted that patient No. 5 with the highest qualitative result $(4+)$ is the first to show a decreased quantitative value on dilution, although the same effect is not exhibited by the other positive sera as compared to the normal sera.

\section{DISCUSSION}

The fundamental observation of this paper is the quantitative relationship between the degree of flocculation and the cholesterol content of the centrifuged complex. This is.not as surprising as may appear at first because the cephalin-cholesterol emulsion may be considered to act as a vehicle to whose surface the active gamma globulin attaches itself in stoichiometric proportions to form the flocculating material. For any given emulsion, it is to be expected that the cholesterol content of the flocculated material would be as true a quantitative index of the active gamma globulin as would be its protein nitrogen or its phospholipid content. Hanger (1) has shown that there is an increase in 
the protein $\mathrm{N}$ in the flocculated material from a positive serum as compared to a blank containing only the emulsion. No experimental work has been performed as yet on the cephalin content of the complex.

The main experimental difficulty which has been encountered in both the qualitative and quantitative method is the difficulty of reproducing the cephalin-cholesterol emulsion or maintaining the stability of the emulsion once it is prepared. The saline blank containing the emulsion, but no serum, has given results varying from 20 to 70 cholesterol units. Occasionally an entire run would exhibit supersensitivity where all the normal controls showed flocculation; at other times a run would show almost complete insensitivity with known $4+$ sera exhibiting little or no flocculation. In each run described above, known normal and $4+$ sera were always included as checks on the proper sensitivity of the emulsion. The pitfalls of the Hanger flocculation test have been discussed in some detail by Mateer (20). However, when the above precautions have been taken, the results obtained were excellent in that all normal individuals, giving a negative qualitative test, usually gave quantitative values below 100 units, while those showing even the slightest degree of flocculation, gave values much greater than 100 units as shown in Table I.

The above data also suggest that each normal individual has his own active gamma globulin level and that this value tends to remain fairly constant as long as the individual remains healthy. For example, the author's own cholesterol unit value, as shown in Table IV, has been about $4 \pm 4$ cholesterol units while that of one of the laboratory technicians has consistently been $95 \pm 5$ cholesterol units. The possibility of establishing an accurate range of cholesterol unit values for all normal individuals and a definite value for a single individual may be one of the main advantages of the quantitative procedure over the original qualitative method.

By the term "active gamma globulin," as used in the above discussion, is meant that portion of the gamma globulin which is not inhibited by a substance present in the electrophoretically separated albumin fraction, as explained by Hanger (21), and which is free to combine with the cephalin-cholesterol emulsion. A small amount of such "active gamma globulin" is present in almost all normal sera as distinguished from the absolute amount of gamma globulin present in the normal sera. A number of investigators have shown that there is an increase in the absolute value of the gamma globulin and a decrease in the albumin fraction in cases of liver disease $(8,10)$ and malaria (22) when these fractions are separated electrophoretically. It is these changes which are determined by the cephalin-cholesterol flocculation reaction.

It should be emphasized that the quantitative cephalin-cholesterol test is not being advocated as a substitute for, or refinement of, the Hanger test. The Hanger test results parallel those of the quantitative test, and since the qualitative test is performed in its entirety before the quantitative test is started, the qualitative results will generally suffice for routine clinical diagnostic or prognostic results. Since a single unit change, e.g., from $1+$ to $2+$, is equivalent to a change of 100 or more cholesterol units in the quantitative test, the test should find its greatest usefulness in studying and measuring accurately the many factors which influence the Hanger reaction so as to lead to an improved test. The data given in Tables II, IV and VI present a clear indication of the advantages that the quantitative test has over the qualitative test for this purpose. In addition to the effect of the dilution of sera on the Hanger reaction, such factors as methods of stabilizing the cephalin-cholesterol emulsion by means of dispersing agents, effect of heating sera at various temperatures, effect of time of standing of sera, effect of variation of temperature at which the flocculation reaction occurs, the use of human gamma globulin as a standard for the reaction, and the effect of various protein fractions on the reaction, etc., are presently under investigation and will be reported in subsequent papers.

It should be further emphasized that, while an attempt was made to select typical cases as representative of a particular disease, the extremely small number of clinical cases does not warrant the drawing of any general conclusions about any disease. They are presented here in the hope that some clinicians will be sufficiently interested in applying the method to a sufficient number of clinical cases so as to establish definite patterns for such diseases. The quantitative test should have its 
greatest clinical value in following clinical cases into the convalescent stage and, because of the relatively slow response of hepatitis and other liver disease cases to treatment, to the investigation of new methods for the treatment of these diseases.

\section{SUMMARY AND CONCLUSIONS}

1. The present investigation deals with the quantitative determination of the cholesterol content of the centrifuged protein-cephalin-cholesterol complex after completion of the qualitative Hanger test.

2. The quantitative cholesterol unit values (after subtraction of the saline blank) of more than 100 normal and pathological sera were determined by the procedure described and the following conclusions were drawn from these results:

a. A direct quantitative relationship exists between the qualitative (Hanger) results and the quantitative cholesterol units.

b. Negative qualitative results gave a wide range of quantitative cholesterol units, i.e., from 0 to 204 units, with those of known normals usually being less than 100 units (average value equals 43 units).

3. Positive qualitative values, i.e., from $1+$ to $4+$, gave cholesterol unit values greater than 100 units. The clinical course of several liver disease cases has been followed by means of serial determinations with the quantitative method. Changes can be detected by this method even when no changes are observed by the Hanger procedure.

4. When the same emulsion is used, the probable error of a single determination in a series has been found to be \pm 4 cholesterol units. With different emulsions, the probable error of a single determination varies from \pm 3 units for a negative qualitative test to an error of \pm 20 units for a $4+$ qualitative result.

5. Experimental evidence is presented to show that the thymol flocculation reaction does not lend itself to quantitative differentiation by means of cholesterol determinations as does the cephalincholesterol flocculation test.

6. The quantitative cephalin-cholesterol flocculation test should find its greatest value in providing the means of accurately determining the various factors which influence the Hanger reaction and for determining the efficiency of new treatments for liver and other diseases.

\section{ACKNOWLEDGMENT}

The author wishes to acknowledge the helpful advice and criticism given to him during the course of this work by Drs. E. A. Kabat and F. M. Hanger, of the College of Physicians and Surgeons of Columbia University Medical School, and M. S. Schrift, Bacteriologist, Manhattan Beach Veterans Administration Hospital. I wish to express my gratitude to Drs. L. M. Fox, Pathologist, and P. W. Spear, Acting Clinical Director, Manhattan Beach Veterans Administration Hospital, for their encouragement of this work, and to Miss Pauline Saifer for the typing and editing of the manuscript.

\section{BIBLIOGRAPHY}

1. Hanger, F. M., The flocculation of cephalin-cholesterol emulsions by pathological sera. Tr. A. Am. Physicians, 1938, 53, 148.

2. Guttman, S. A., Potter, H. R., Hanger, F. M., Moore, D. B., Pierson, P. S., and Moore, D. H., Significance of cephalin-cholesterol flocculation test in malarial fever. J. Clin. Invest., 1945, 24, 296.

3. Evans, A. S., Liver involvement in infectious mononucleosis. J. Clin. Invest., 1948, 47, 106.

4. Pohle, F. J., and Stewart, J. K., The cephalincholesterol flocculation test as an aid in the diagnosis of hepatic disorders. J. Clin. Invest., 1941, 20, 241.

5. Rosenberg, D. H., and Soskin, S., Comparison of the cephalin-cholesterol flocculation test with various criteria of liver function. Am. J. Digest. Dis., 1941, 8, 421.

6. Clay, H. L., and Moore, J. W., Cephalin-cholesterol ether emulsion flocculation test. Clinics, 1942, 1, 980.

7. Hanger, F. M., Serological differentiation of obstructive from hepatogenous jaundice by flocculation of cephalin-cholesterol. J. Clin. Invest., 1939, 18, 261.

8. Kabat, E. A., Hanger, F. M., Moore, D. H., and Landow, H., Relation of cephalin flocculation and colloidal gold reactions to the serum proteins. $\mathrm{J}$. Clin. Invest., 1943, 22, 563.

9. Maclagan, N. F., and Bunn, D., Flocculation tests with electrophoretically separated serum proteins. Biochem. J., 1947, 41, 580.

10. Moore, D. B., Pierson, P. S., Hanger, F. M., and Moore, D. H., Mechanism of positive cephalincholesterol flocculation in hepatitis. J. Clin. Invest., 1945, 24, 292.

11. Neefe, J. R., and Reinhold, J. G., Photosensitivity as a cause of falsely positive cephalin-cholesterol flocculation tests. Science, 1944, 100, 83. 
12. Dick, A., The cephalin-cholesterol flocculation reaction as a test of hepatic function. Brit. M. J., 1945, 1, 182.

13. Saifer, A., and Kammerer, O. F., Photometric determination of total cholesterol in plasma or serum by a modified Liebermann-Burchard reaction. J. Biol. Chem., 1946, 164, 657.

14. Neefe, J. R., Results of hepatic tests in chronic hepatitis without jaundice; correlation of clinical course and liver biopsy findings. Gastroenterology, 1946, $7,1$.

15. Maclagan, N. F., Thymol turbidity test, a new indicator of liver dysfunction. Nature, 1944, 154, 670.

16. Bruger, M., Fractional cephalin-cholesterol flocculation in hepatic disease. Science, 1943, 97, 585.

17. Mirsky, I. M., and von Brecht, R., The fractional cephalin-cholesterol flocculation test. Science, 1943, 98, 499.
18. Kunkel, H. G., and Hoagland, C. L., Persistence of elevated values for the thymol turbidity test following infectious hepatitis. Proc. Soc. Exper. Biol. \& Med., 1946, 62, 258.

19. Recant, L., Chargaff, E., and Hanger, F. M., Comparison of the cephalin-cholesterol flocculation with the thymol turbidity test. Proc. Soc. Exper. Biol. \& Med., 1945, 60, 245.

20. Mateer, J. G., Liver function tests. Conference on Liver Injury. 2nd meeting, Josiah Macy Foundation, New York, N. Y., 1944, 39.

21. Hanger, F. M., Conference on Liver Injury. 3rd meeting, Josiah Macy Foundation, New York, N. Y., 1945, 114.

22. Guttman, S. A., Potter, H. R., Hanger, F. M., Moore, D. B., Pierson, P. S., and Moore, D. H., Significance of cephalin-cholesterol flocculation test in malarial fever. J. Clin. Invest., 1945, 24, 296. 